Dept. of Poultry Diseases,

Animal Health Research Institute, Zagazig.

\title{
LABORATORY EVALUATION OF SELECTED DISINFECTANTS ON GUMBORO DISEASE VIRUS
}

(With 2 Tables)

\author{
By \\ H.A.A. BAYOUMIE and I.A.A. MOHAMED*
}

* Dept. of Avian and Rabbit Med., Fac. of Vet. Med., Zagazig Univ.

(Received at 19/11/2008)

\section{التقييم المعملى لبعض المطهرات المختارة ضد فيروس الجامبورو \\ هشام أحمد عبل البلبيع محد ببيومى، عماد عزمى عوضين محمد}

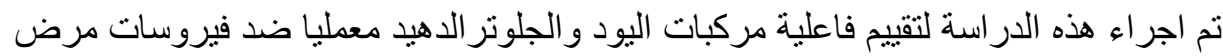

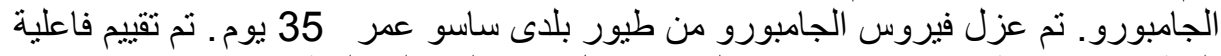

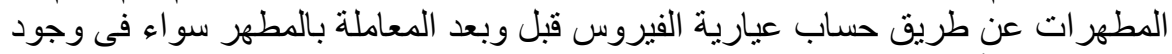

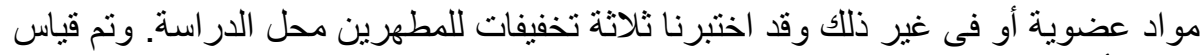

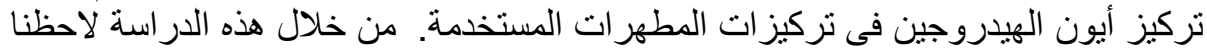

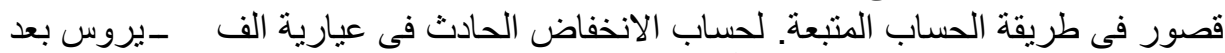

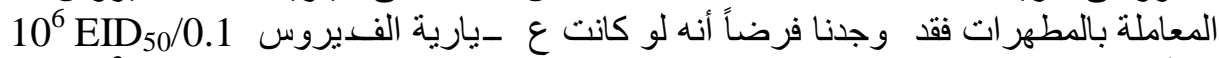

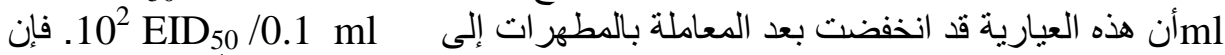

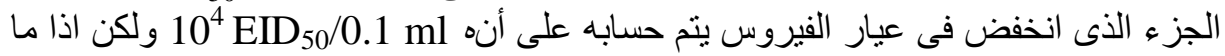

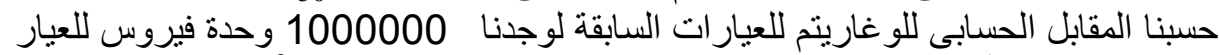

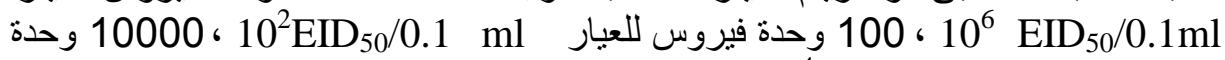

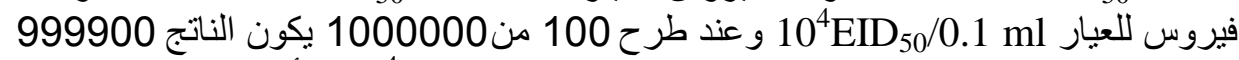

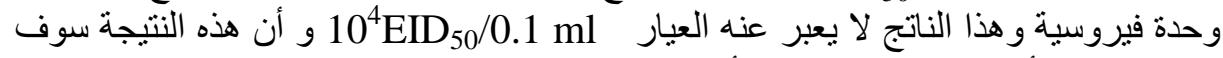

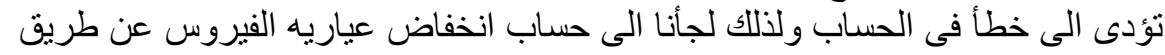

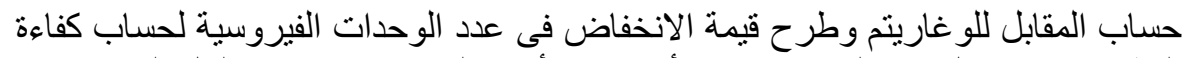

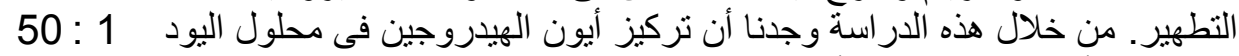

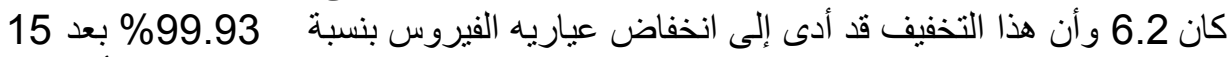

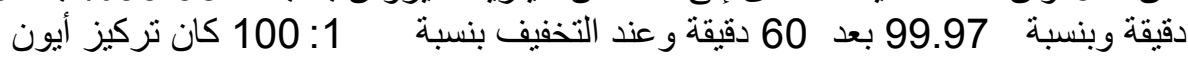

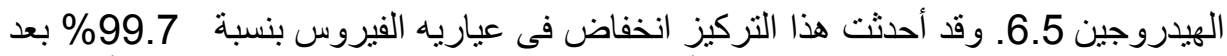

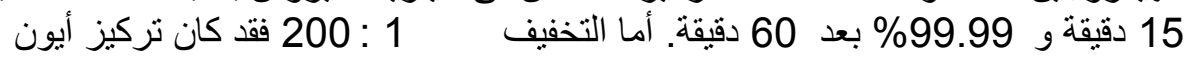

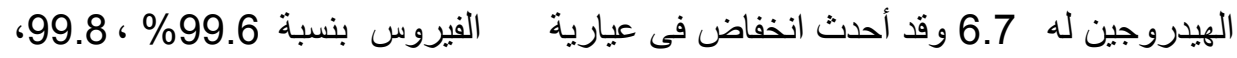

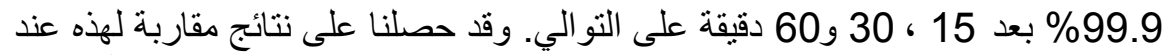
استخدام مو اد عضوية بنسبة 40\% و وبالر غم من اختلاف هذه النتائج عن نتائج الآخرين الذن 


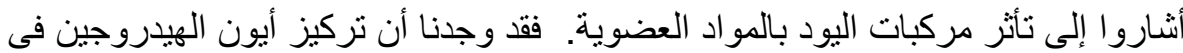

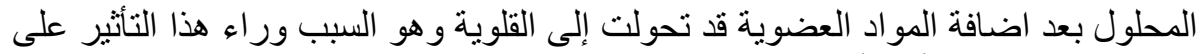

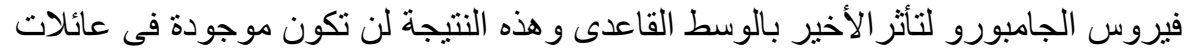

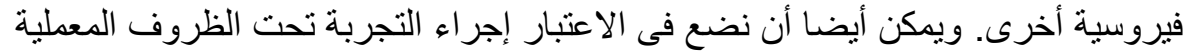

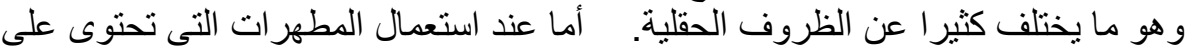

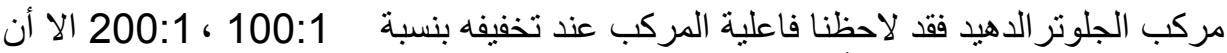

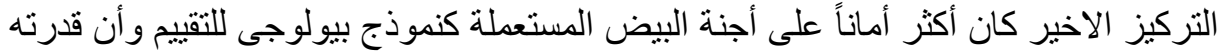

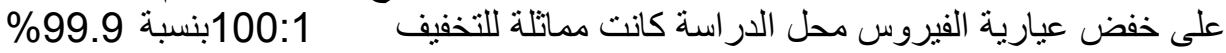

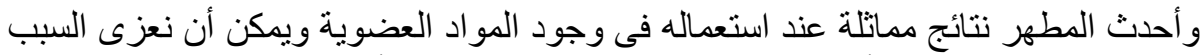

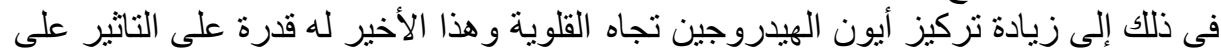
فيروس الجامبورو.

\section{SUMMARY}

The efficacy of iodine and glutraldehyde containing compounds against infectious bursal disease virus (IBDV) was assayed by comparing the virus titer before and after exposure to each disinfectant. The test was conducted at room temperature in presence or absence of organic matter " $40 \%$ foetal bovine serum". The two tested disinfectants were effective against IBDV under all test conditions and at the dilutions used 1:50, 1:100 and 1:200. In this paper a new method for calculation of viral regression after disinfection, was devised as it gives a more reasonable calculation.

Key words: Chicken, gumboro disease, disinfectant

\section{INTRODUCTION}

Infectious bursal disease is one of the widely spreaded acute, highly contagious diseases of young chickens that had lymphoid tissue target with special predilection for the bursa of fabricius (Lukert and Saif, 2003).

Disease prevention depends on proper disinfection of poultry premises, proper management and specific active immunization (Bayoumie, 1997).

Faragher (1972) stated that contaminated poultry premises is the main source for IBDV infection, this is helped by the very stable physicochemical properties of IBDV (Benton et al., 1967). 
The short life span of broilers (30-35 day) is insufficient to generate active immunity. For this, disease prevention strategies should run parallel to ensure successful poultry operation (Bayoumie, 1997).

Few scientific researches about chemical disinfection of IBDV are available. The present work evaluates commercially available iodine, and glutraldehyde containing disinfectant on IBDV in presence or absence of organic materials after different reaction times.

\section{MATERIALS and METHODS}

\section{A-Materials:}

\section{1- Samples for isolation of IBDV:}

Samples for IBDV isolation were collected from a native saso chicken flock 35 day old exhibiting $80 \%$ morbidity and 50\% mortality. The affected flock was showing signs and post mortem lesion specific for IBD as described by Lukert and Saif (2003). Severely hemorrhagic and inflammed bursae were collected for virus isolation (Rosenberger et al., 1998).

\section{2- IBDV live vaccine:}

An intermediate (D-78) live vaccine strain kindly obtained form Prof. Dr. S.Assily, Poultry Vaccine Dept., Serum \& Vaccine Res. Inst. El-Abbassia.

\section{3- IBDV reference antigen and antisera:}

IBDV "serotype 1" reference antigen and antisera were obtained from the international marketing center, Cairo, Egypt.

\section{4- Test system:}

Embryonated chicken eggs (ECE) from a small native breeder flock that received influenza vaccination only were used for virus isolation, viral propagation, viral identification and testing disinfection potency.

\section{5- Foetal bovine serum:}

Foetal bovine serum produced by "life technologies" obtained from Bardisi medical. This serum was virus and mycoplasma tested, and it was heat inactivated at $56^{\circ} \mathrm{C}$ for $30 \mathrm{~min}$ before use.

\section{6- Tested disinfectants:}

a- Glutraldehyde containing compound, (62.5 gm/liter) was tested as antiviral agent against IBDV, at dilutions 1:50, 1:100 and 1:200. 
b- Iodine containing compound $2.5 \%$ active iodine w/v. was similarity tested.

\section{7- Water diluents:}

Under ground water from a commercial poultry farm was used after being autoclaved.

\section{8- Source of organic matter (OM):}

$40 \%$ solution of foetal bovine serum in autoclaved distilled water was prepared, and was used as a source for organic matters as adapted by Ismail et al. (1976).

\section{B- Methods:}

\section{1- Sample preparation for viral assay:}

Collected bursae were grounded. AGPT against reference IBDV antigen and antisera was performed (Beard 1980), positively reacting bursae, were further processed for virus isolation (Rosenberger et al. 1998, Senne, 1998). The CAM route was chosen for virus isolation, specific mortality and PM lesion were recorded as previously described by Hitchner (1970). Examination for heat resistance $\left(56^{\circ} \mathrm{C}\right.$ for $\left.5 \mathrm{hrs}\right)$ was performed as described by Benton et al. (1967). Virus neutralization was performed according to Thayer and Beard (1998).

\section{2- pH measurement:}

$\mathrm{pH}$ of tested concentration for both disinfectants in presence or absence of $(\mathrm{OM})$ was determined using an electrical $\mathrm{pH}$ meter (Jenway 3510).

\section{3- Safety of disinfectant for the test system:}

The tested dilutions of each disinfectant was inoculated in 5 ECE, daily mortality was recorded after neglecting the non specific mortality.

\section{4- Testing Virucidal activity of the selected disinfectants in presence or absence of organic matters:}

Isolated IBDV was 10 fold serially diluted once using sterile saline and another in $40 \%$ foetal bovine serum. Selected test disinfectant were diluted 1:50, 1:100 and 1:200 using the autoclaved under ground water as diluent. A $0.5 \mathrm{ml}$ of the viral saline suspension or viral serum suspension was added to $0.5 \mathrm{ml}$ of the tested disinfectant dilutions. A reaction time 15, 30 and $60 \mathrm{~min}$. was given for this mixture. Each dilution at every reaction time was inoculated in 5 ECE via allantioc sac route (AS) to ensure precise reaction time limits.

\section{5- Calculation of disinfectant potency:}


Mortality of inoculated chicken eggs was daily recorded and was specifically confirmed through the examination of inoculated CAM in AGPT. Titer calculation was preformed according to Spearman and Karber Cunningham (1973). Antilog 10 of the obtained titer was calculated. Reduced virus titer (c) was calculated by subtracting the antilog of post disinfection titer (b) from the antilog of virus control (a). The percent of disinfection success (d) is obtained by dividing c/a.

\section{6- Preparation of IBDV hyperimmune sera:}

Some of the fertile chicken eggs were used to hatch a day old chicks. The latter were eye inestillated repeatedly every four days with the live intermediate IBDV vaccine until birds became 60 day old, collected sera were examined with AGPT for IBDV precipitating antibodies.

\section{RESULTS}

\section{1- Clinical picture and necropsy findings in the field case:}

The examined native saso flock was 35 day old, showed $80 \%$ morbidity and 50\% mortality. The PM lesion observed was, dehydrated darkened skeletal muscles with subcutaneous hemorrhage on thigh muscles; urate deposition in the urters; enteritis, the liver is enlarged with peripheral areas of infarction, hemorrhages at the juncture of proventriculus and gizzard, spleen is mildly enlarged with necrotic foci on its surface, and the bursae were enlarged and surrounded by gelatinous hemorrhagic fluid. Their plicae were also hemorrhagic.

\section{2- Results of viral assay:}

\section{a- Virus isolation:}

Embryo mortality due to inoculated bursal homogenate is shown in Table (1). Precipitins specific for IBDV was observed after the $2^{\text {nd }}$ passage. The $3^{\text {rd }}$ passage was performed for further adaptation on test system. The PM lesion observed in inoculated eggs via CAM route was congestion of embryo, paleness of liver with mild thickening of CAM. Positive reaction of infected CAM in AGPT against reference IBDV antigen and antisera is a preliminary indication for successful isolation of IBDV.

\section{b- Results of viral titration, resistance to heat inactivation and virus neutralization:}

Results are shown in Table (1) 
Table 1: Virological assay.

\begin{tabular}{|c|c|c|c|c|c|c|c|c|c|c|}
\hline \multirow{2}{*}{ Items } & \multicolumn{6}{|c|}{ Tested dilutions } & \multirow{2}{*}{ AGPT } & \multirow{2}{*}{ Virus titer } & \multirow{2}{*}{\begin{tabular}{|c|} 
Antilog \\
10 for \\
virus titer
\end{tabular}} & \multirow{2}{*}{$\begin{array}{c}\text { Neutralized } \\
\text { viruses }\end{array}$} \\
\hline & -1 & -2 & -3 & -4 & -5 & -6 & & & & \\
\hline Viral propagation $\mathrm{P}$ & $0 / 5$ & & & & & & -- & & & \\
\hline $\mathrm{P}$ & $2 / 5$ & & & & & & + & & & \\
\hline $\mathrm{P}$ & $3 / 5$ & & & & & & + & & & \\
\hline Viral titration & $5 / 5$ & $5 / 5$ & $5 / 5$ & $5 / 5$ & $3 / 5$ & $2 / 5$ & & $10^{5.5} \mathrm{EID}_{50} / 0.1 \mathrm{ml}$ & 316228 & \\
\hline $\begin{array}{l}\text { Heat inactivation } \\
56^{\circ} \mathrm{C} \text { for } 5 \mathrm{hrs} \text {. }\end{array}$ & $5 / 5$ & & & & & & + & & & \\
\hline \multicolumn{11}{|l|}{ V. neutralization } \\
\hline V.+ positive serum & $5 / 5$ & $3 / 5$ & $1 / 5$ & $0 / 5$ & $0 / 5$ & $0 / 5$ & & $10^{2.3} \mathrm{EID}_{50} / 0.1 \mathrm{ml}$ & 199 & \multirow{2}{*}{$\begin{array}{l}125693 \\
(99.8 \%)\end{array}$} \\
\hline V.+ negative serum & $5 / 5$ & $5 / 5$ & $5 / 5$ & $4 / 5$ & $3 / 5$ & $1 / 5$ & & $10^{5.1} \mathrm{EID}_{50} / 0.1 \mathrm{ml}$ & 125892 & \\
\hline
\end{tabular}

\section{3-Results of pH measurement and disinfection potency with iodine:}

The $\mathrm{pH}$ of diluted iodine 1:50 was 6.2 this dilution reduced virus titer $99.93 \%$ after 15 min. reaction and the reduction was $99.97 \%$ after $60 \mathrm{~min}$. the $\mathrm{pH}$ of diluted iodine 1:100 was 6.5, disinfection success was $99.7 \%$ after 15 min. and $99.9 \%$ after 60 min., while the $\mathrm{pH}$ of diluted iodine 1:200 was 6.7 and the disinfection success was 99.7, 99.84 and $99.9 \%$ after 15,30 and 60 min. respectively.

The $\mathrm{pH}$ of diluted iodine 1:50 in $40 \%$ foetal bovine serum was 7.26 this dilution reduced virus titer $99.6,99.8$ and $99.9 \%$ at 15, 30 and $60 \mathrm{~min}$. reaction times respectively, comparable results were obtained at dilutions 1:100 and 1:200 at the same test conditions (Table 2).

\section{4- Results of $\mathrm{pH}$ measurement and disinfection potency with glutraldehyde containing compound:}

The disinfection potency of dilution 1:50 of the glutraldehyde containing compound couldn't be tested because it killed all inoculated $\mathrm{ECE}$ in the safety trial. The $\mathrm{pH}$ measurement of dilutions 1:100 and $1: 200$ was 7.5 and 7.6 respectively and the disinfection success was 99.9\% similar results of disinfection success was obtained in presence of organic matter at $\mathrm{pH}$ measurement 8.6 and 8.78 for dilutions 1:100 and 1: 200 respectively. 
Assiut Vet. Med. J. Vol. 55 No. 120 January 2009

Table 2: Virucidal activity of iodine, glutraldehyde containing disinfectant in presence or absence of organic matters, with different dilutions and reaction times.

\begin{tabular}{|c|c|c|c|c|c|c|c|c|c|c|c|c|c|c|c|c|c|c|c|c|c|c|}
\hline \multicolumn{13}{|c|}{ 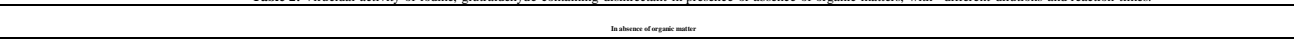 } & \multicolumn{10}{|c|}{ 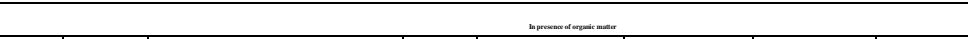 } \\
\hline \multirow{2}{*}{ 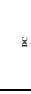 } & \multirow{2}{*}{$\frac{1}{2}$} & \multirow{2}{*}{$\approx$} & i & \multicolumn{3}{|c|}{ restatatisus } & \multirow{2}{*}{ 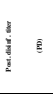 } & \multirow{2}{*}{ '. } & \multirow{2}{*}{1} & \multirow{2}{*}{ - 1} & \multirow{2}{*}{. } & \multirow{2}{*}{ 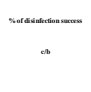 } & \multirow[t]{2}{*}{ "n } & \multirow{2}{*}{ 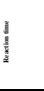 } & \multicolumn{3}{|c|}{ rementantures } & \multirow[t]{2}{*}{ ppoutar } & \multirow{2}{*}{.". } & \multirow{2}{*}{1} & \multirow{2}{*}{$\therefore \stackrel{1}{1}$} & \multirow{2}{*}{ 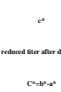 } \\
\hline & & & i & $\therefore$ & 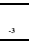 & + & & & & & & & & & $\therefore$ & 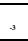 & + & & & & & \\
\hline \multirow{3}{*}{ iso } & \multirow{3}{*}{25} & \multirow{3}{*}{62} & is & ${ }_{25}$ & ${ }_{25}$ & us & 23 & ${ }_{\text {imow }}$ & \multirow{18}{*}{ ss } & & stass vip & wox & & is & $\triangle$ & $s$ & 18 & 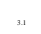 & novir & & & тиети \\
\hline & & & $\infty$ & 36 & as & is & 2.1 & 12asp & & & 3terest & $m s 6$ & $2 x$ & $3 n$ & 36 & 25 & is & 25 & sour & & & $31522 y p$ \\
\hline & & & $\infty$ & ${ }_{25}$ & as & os & 10 & miv & & & маны й & $m$ & & " & $x$ & 15 & is & 25 & 3ww & & & эмовоге \\
\hline \multirow{3}{*}{ H:on } & \multirow{3}{*}{ is } & \multirow{3}{*}{ "s. } & 15 & 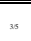 & 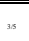 & is & 20 & 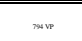 & & & 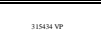 & 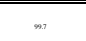 & & is & 4 & 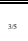 & 2 & 3 & 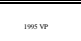 & & & 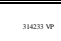 \\
\hline & & & .6 & 36 & 25 & us & 25 & $36 w$ & & & 3 & $m$ & $2 \pi$ & 20 & 4 & 25 & is & 29 & swow & & & Issatsp \\
\hline & & & $\infty$ & 26 & is & us & 2.1 & nosw & & & stereve we & msso & & 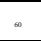 & 36 & is & is & $2 s$ & Msw & & & 11920202 \\
\hline . & & & is & is & is & $\overline{\text { os }}$ & 29 & 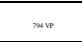 & & & 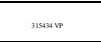 & $\overline{m o n}$ & & 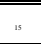 & 4 & 18 & 18 & 3 & 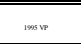 & & & 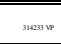 \\
\hline 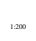 & as & .7. & . & 36 & 25 & is & 27 & sol ip & & & 36524 ip & sost & $s$ & 3 & ${ }_{46}$ & ${ }_{35}$ & is & 3 & nesse & & & мเsтup \\
\hline & & & $\infty$ & ${ }_{36}$ & ${ }_{25}$ & ${ }_{0.5}$ & 25 & ${ }_{316 w}$ & & . & 1 & $m$ & & an & 4 & 25 & is & 29 & swer & $s$ & & $313 \operatorname{sen} 2$ \\
\hline & & & is & & & & & & & & & & & & & & & & & 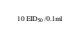 & 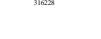 & \\
\hline Isan & $s$ & ${ }^{24}$ & .6 & & & & & & & & & & $s$ & & & & & & & & & \\
\hline & & & $\infty$ & & & & & & & & & & & & & & & & & & & \\
\hline & & & s. & 24 & is & of & 225 & $m$ & & & suas in & 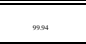 & & is & 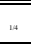 & 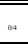 & 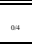 & is & & & & \\
\hline nom & ${ }_{2 s}$ & 76 & $\infty$ & " & 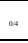 & of & is & uा & & & satrove & son & 36 & 3 & ${ }_{14}$ & 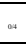 & ${ }^{14}$ & is & & & & \\
\hline & & & $\infty$ & " & ou & of & is & याए & & & & & & $\mathrm{an}$ & ${ }_{14}$ & 14 & "14 & is & & & & \\
\hline & & & ${ }_{15}$ & 24 & ${ }_{14}$ & ${ }_{0.4}$ & 2 & 31ИP & & & & & & is & ${ }_{14}$ & 14 & 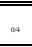 & is & आ14 & & & נatsine \\
\hline izm & as & & . & ${ }_{14}$ & ${ }^{04}$ & ${ }^{04}$ & is & 3110 & & & & & $\mathrm{sx}$ & ${ }_{30}$ & ${ }_{14}$ & ${ }^{14}$ & ${ }^{14}$ & is & & & & \\
\hline & & & $\infty$ & 14 & 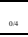 & ${ }_{04}$ & is & $n_{n, p}$ & & & & & & (n) & 14 & ${ }^{14}$ & ${ }^{\mathrm{Na}}$ & is & & & & \\
\hline
\end{tabular}




\section{DISCUSSION}

Disinfection is one of the measures taken to break the cycle of infectious diseases but it is not adequate alone Linton et al. (1987). For implementing a disinfection plan, there are several important areas to be addressed, this include assessment of cleaning, washing, disinfection and evaluation (Dvorak, 2005).

Before selecting a disinfectant to use, several factors must be considered. Some disinfectants are effective for routine disinfection protocols while others are necessary for outbreak situation.

For effective disinfection protocol, consideration should be given to the targeted microorganism, this involves the characteristics of a specific disinfectant and environmental issues, additionally the health and safety of personals (Ewart, 2001; Quinn, 2001; Sawicki, 2002; Shulaw and Bowman, 2001; Grooms, 2003).

Test methods for evaluating virucide are more complex than those adapted for evaluating bactericides, because the living host required for the recovery of virus is susceptible for the toxic effect of disinfectant (Linton et al., 1987). This was limiting factor prevented us from testing the potency of 1:50 dilution of the glutraldehyde containing disinfectant because this dilution killed the inoculated ECE, but the mortality was $40 \%$ in ECE at dilution 1:100 of glutraldehyde containing compound (Table 2). As for iodine dilution 1:50 killed 40\% of ECE while dilution 1:100 killed 20\% ECE in the safety trials. Dialysis has been proposed as a mean of removing or reducing the concentration of disinfectant in a mixture to a level that wouldn't be toxic for the host system. (Blackwell and Chen, 1970). Boudouma et al. (1984) had overcome this limitation by ultra filtration, while Linton et al. (1987) pointed to the value of density gradient ultracentrifugation to solve this problem. In our study dilution 1:200 proved safe for ECE and the percent of disinfection success was comparable to the concentrated dilutions 1:100, 1:200 for both tested disinfectants. So we didn't had to go through this troubling procedures.

Glutraldehyde is saturated 5-carbon dialdehyde $\left(\mathrm{C}_{5} \mathrm{H}_{8} \mathrm{O}_{2}\right)(\mathrm{CHO}-$ $\mathrm{CH}_{2}-\mathrm{CH}_{2}-\mathrm{CH}_{2}-\mathrm{CHO}$ ) (Linton, 1987). It is characterized by high efficiency and broad spectrum. It achieves its effect through denaturation of protein and disrupting nucleic acid (Ewart 2001). It is non corrosive to metal, rubber or plastics (Morley, 2003). Thus it avoids the limitations 
met with formaldehyde (Lenton, 1987), but they are highly irritating to humans by contact or inhalation and they are potentially carcinogenic (Green, 1998; Quinn, 2001; Morley, 2002). Thus protective equipments should be worn during its usage (Dvorak, 2005). The antimicrobial efficacy of glutraldehyde depends mainly on $\mathrm{pH}$ and it is more active in alkaline $\mathrm{pH}$, and not affected by the presence of organic matter in disinfection of IBDV (Linton, 1987). This may be due to the increased alkalinity of solution which in turn kills IBDV.

In the present study the glutraldehyde containing compound couldn't be tested at dilution 1:50. At dilution 1:100 40\% mortality in ECE eggs was obtained; dilution 1:200 was safe for ECE and produced a disinfection success $99.9 \%$ in presence or absence of organic matter these results were similar to those obtained at 1:100 dilution so from economic point of view 1:200 dilution can be used without risk for disinfection of IBDV. Meulemans and Halen (1982) found that aldehyde and complex disinfectant containing aldehyde reduced $4 \log 10$ or more in the titer of IBDV; the virucidal activity was maximum after $60 \mathrm{~min}$. In the present study results of disinfection success were nearly equal at 15 , 30 and $60 \mathrm{~min}$. respectively.

Iodine compounds are broad spectrum compounds of low toxicity, low cost, easy to use, they do lose potency overtime, and not active at high temperature (Jeffrey, 1995). Since these compounds lose activity quickly in the presence of organic matter; they must be applied to a thoroughly cleaned surfaces (Green, 1998; Kennedy et al., 2000; Shulaw and Bowman 2001; Grooms, 2003).

Iodine function by denaturating proteins, thus interfere with enzymatic system of microorganisms (Jeffrey, 1995); concentrated iodines irritates the skin, stains clothes, damages rubber and metals (Shulaw and Bowman, 2001), they are also inactivated by QACS and organic matter. Benton (1967) treated IBDV with various concentrations of iodine complex, phenolic derivatives and QACS for a period of $2 \mathrm{~min}$. at $23^{\circ} \mathrm{C}$ and found that iodine is the only disinfectant having deleterious effect on IBDV. On the other hand, Meulemans and Halen (1982) found that iodines were not effective as disinfectant for IBDV so they didn't test its efficacy in presence of organic matter.

In the present study iodines were proved effective for disinfection against IBDV at the tested dilutions and the different reaction times, their activity in presence of organic matter was $99 \%$.This 
effectiveness may be due to the alkaline $\mathrm{pH}$ recorded in presence of organic matter, the later had a deleterious effect on IBDV as mentioned by (Benton, et al., 1967) and this may not be the situation with other viruses resisting alkalinity.

In the present study, disinfection success was evaluated by comparing log virus titer before and after exposure to each dsinfectant. Suppose!! Virus control is $\log 10^{6} \mathrm{EID}_{50} / 0.1 \mathrm{ml}$ and the titer after disinfection was reduced to $\log 10^{2} \mathrm{EID}_{50} / 0.1 \mathrm{ml}$. The difference is $10^{4}$ as adapted by Thayer and Beard (1998). The antilog of $10^{6}=1000000$ $\mathrm{VP}(\mathrm{a})$., the anti $\log$ of $10^{2}=100 \mathrm{VP}(\mathrm{b})$, and the antilog of $10^{4}=10000$ $\mathrm{VP}(\mathrm{c})$ calculation of titer reduction $\mathrm{c} / \mathrm{a} \%=1 \%$ in one hand and the $10^{4}$ reduction titer doesn't signify the actual drop in viral titer in another hand .For this reason we adapted another method for calculation as follow:

Antilog of $10^{6}=1000000$ as virus control; antilog $10^{2}=100$ after disinfection for calculation of disinfection success $=1000000 \mathrm{VP}-100$ $\mathrm{VP}=999900$ so the percent of disinfection success is $99.99 \%$ and this is more logic calculation. This method can be adapted in calculation of neutralization and viral regression in calculation of relatedness.

\section{REFERENCES}

Bayoumie, HAA (1997): Immune response in chickens after simultaneous vaccination against Newcastle and Gumboro disease viruses. MVSc. Thesis, Poult. Dis. Fac. of Vet. Med., Zag. Univ.

Beard, C.W. (1980): Serologic procedures in: Isolation and identification of Avian pathogens. pp.131. AAAP. Dept. of Vet. Microbial. Texas A \& M Univ. college station Texas.

Beard, C.W. (1989): Serologic procedures in A laboratory manual for the isolation and identification of Avian pathogens. $3^{\text {rd }}$ Ed. Edited by Purchase, G.H.; Lawrence, H. Arp., Domermuth, C.H., Pearson, J. E.. Kendall/ Hunt Publishing Company.

Benton, W.J.; Cover, M.S.; Rosenberger, J.K. and Lake, R.S. (1967): Physicochemical properties of infectious bursal agent (IBA). Avian Dis. 11: 438-445. 
Blackwell, J.H. and Chen, J.H.S. (1970): Effect of various germicidal chemicals on H.Ep 2 cell culture and Herpes simplex virus. J. Assoc. of Official Analytical Chemists. 53: 1229-36.

Boudouma, M.; Enjalbert, L. and Dider, J. (1984): Simple method for the evaluation of Antiseptic and disinfectant virucidal activity. J. Virological Methods, 9: 271-276.

Cunningham, C.H. (1973): A laboratory guide in virology. $7^{\text {th }}$ Ed., Burgess Publishing Company.

Dvorak, G. (2005): Disinfection 101. The Center for Food Security and Public Health. Iowa State Univ. www.cfsph.iastate.edu.

Ewart, S.L. (2001): Disinfectants and control of environmental contamination. Pp. 1371-1380 in large animal internal medicine. Smith, B.L. editor, $3^{\text {rd }}$ ed. St. Louis: Mosby.

Faragher, J.T. (1972): Infections bursal disease of chickens. Vet. Bull. 42: 361-369.

Green, C.E. (1998): Environmental factors in infectious disease in: infections diseases of dogs and cat.Pp673-683. ed. greene, C.E. Philadelphia WBSaunders Company

Grooms, D. (2003): Biosecurity guide for livestock farm. Michigan State Univ. Extension Bull E 2842 April 2003.

Hitchner, S.B. (1970): Infectivity of infections bursal disease virus for embryonating eggs. Poult. Sci. 45: 511-516.

Ismail, A.; Woelfing, P.E. and Geissler, H. (1976): Antiviral activity of some chemical disinfectants against some poultry pathogenic viruses. 1-Newcastle disease virus (NDV). Assuit Vet. Med. J. 3: 217-229.

Jeffery, D.J. (1995): Chemicals used as disinfectants the ingredients and enhancing additives. Rev. Sci. Tech. Offint. Epiz. 14: 57-74

Kennedy, J.; Bek, J. and Griffin, D. (2000): Selection and use of disinfectants. Univ. of Nebraska Cooperative Extension Goo1410-A Nov. 2000.

Linton, A.H.; Hugo, W.B. and Rusel, A.D. (1987): Disinfection in veterinary and farm animal practice. Blackwell Scientific Publications.

Lukert, P.D. and Saif, Y.M. (2003): Infectious bursal disease in : diseases of poultry. Pp. 161-180. $11^{\text {th }}$ ed., edited by Saif, Y.M., Lowa State Press, a Blackwell Publishing Company. 
Meulemonas, G. and Halen, P. (1984): Efficacy of some disinfectants against infectious bursal disease virus and Avian Reo virus. Vet. Rec.111: 412-413.

Morley, P.S. (2002): Biosecurity of veterinary practices. Vet. Clin. Food. Anm. 18: 133-155.

Quinn, P.J. and Markey, B.K. (2001): Disinfection and disease prevention in veterinary medicine in: Disinfection, sterilization and preservation. Pp 106-1103, ed, Block, SS. $5^{\text {th }}$ ed. Philadelphia: Lippincott, Williams \& Wilkins.

Rosenberger, J.K.; Saif, Y.M. and Jackwood, D.J. (1998): Infectious bursal disease in: A laboratory manual for the isolation and identification of avian pathogens. $4^{\text {th }}$ Ed., Pp. 215. Edited by Swayne, D.E.; Glisson, J.R.; Jackwood, M.W.; Pearson, J.E. and Reed, W.M. AAAP Univ. of Pennsylvania New Balton Center Kennett square, PA. 19348-1692.

Sawicki, T. (2001): Biological safety officer, USDA ARS plum animals disease center field decontaminaton technique. Foreign animal disease diagnostic training, May 2002.

Schliesser, Th. (1979): Testing of chemical disinfectants for veterinary medicine. Hygiene and medizin. 4 : 51-60.

Senne, D.A. (1998): Virus propagation in embryonating eggs in: A laboratory manual for the isolation and identification of avian pathogens. $4^{\text {th }}$ Ed., Pp. 235. Edited by Swayne, D.E.; Glisson, J.R.; Jackwood, M.W.; Pearson, J.E. and Reed, W.M. AAAP Univ. of Pennsylvania New Balton Center Kennett square. PA. 19348-1692

Shulaw, W.P. and Bowman, G.L. (2001): Disinfection in on-farm biosecurity procedures. The Ohio State University Extension Fact. Sheet VME-8-2001.

Thayer, S.G. and Beard, C.W. (1998): Serologic procedure in: A laboratory manual for the isolation and identification of avian pathogens. $4^{\text {th }}$ Ed., Pp. 255. Edited by Swayne, D.E.; Glisson, J.R.; Jackwood, M.W.; Pearson, J.E. and Reed, W.M. AAAP Univ. of Pennsylvania New Balton Center Kennett square PA. 19348-1692. 
Assiut Vet. Med. J. Vol. 55 No. 120 January 2009 